\title{
Improving Disaster Management System in Korea for Effective Disaster Response
}

\author{
Youngjin Jang ${ }^{*}$, and Hongsik Yun ${ }^{\mathrm{a}}$
}

\begin{abstract}
Urbanization and industrialization have made disaster large and complex. The development of society has raised the public consciousness level, but the level of safety still remains in the past. In this situation, safety from various disasters and risks became important national policy.

Since the government has emphasized the necessity of safety from disasters and risks, it has enacted safety related laws such as "Basic Act on Disaster and Safety Management" Although efforts have been made to formulate and legislate policies to protect the body and property, safety accidents are still increasing.

At present, the importance of disaster management is increasing. This paper is aiming at suggesting improvement plan of disaster management policy in Korea.
\end{abstract}

Keywords - disaster, safety, management, government.

\section{INTRODUCTION}

In the disaster history of Korea, various government policies such as supplementation and maintenance of disaster management organization and system and enactment of special law were announced every time a large-scale disaster occurred, and some were implemented and improved. However, Numerous large-scale disasters have been repeated. The loopholes in the disaster management system of our society are no different from systematic restructuring of the government.

The April accident in April 2014 is an example of the importance of safety awareness and disaster management. In order to carry out the disaster management work in the case of the Sewol ferryincident, the National Security Agency was unified by dismantling the Maritime Police Agency and the National Emergency Management Agency and transferring some functions of the Ministry of Maritime Affairs and Fisheries to the Ministry of Maritime Affairs and Fisheries. In this respect, it has been pointed out that the function as disaster management system and control tower of the National Security Agency is insufficient. However, every time such a large disaster occurs, a new law has been enacted and the organization responding to the disaster is reorganized.

The purpose of this study is to propose an alternative for the efficient system of disaster management based on current disaster management policy in Korea.

* The master's course, Interdisciplinary Program in Crisis, Disaster and Risk Management, Sungkyunkwan University, Suwon Korea 440-746, Korea;

${ }^{a}$ School of Civil and Architecture Engineering, Sungkyunkwan University, Suwon, Republic of Korea

\section{BODY}

\section{A. Current Status of Disaster Management System in Korea}

The disaster management in Korea is until disaster and safety management basic law is enacted. In the event of a major disaster, the natural disaster is created according to the natural disaster countermeasures law, and the disaster countermeasures headquarters is created. In the case of disaster management system, individual laws were scattered by each department, and the issue of efficiency of disaster safety management was raised. However, after the Basic Law on Disaster and Safety Management was enacted on March 11, 2004, it became an integrated management system. However, the central government has some integrated disaster management system, but it seems to be insufficient at the local government level.

\section{B. Status of Foreign Disaster Management System}

\section{United States}

The US disaster management organization is divided into federal, provincial, and local government organizations, and each organization clearly distinguishes its roles and duties. There are DHS and FEMA as federal organizations. State and local government organizations are different in each region, but they are usually managed as permanent organizations and emergency management organizations.

In the event of a disaster, the local government is primarily responsible for responding to the disaster, and in the event of a disaster that the local government can not afford, it asks the state for assistance. In the event of a major disaster that the provincial government can not afford, the governor will notify the Federal Emergency Management Agency of the disaster and ask the President for assistance.

\begin{tabular}{|l|l|l|}
\hline division & $\begin{array}{l}\text { Disaster } \\
\text { Management } \\
\text { Organization }\end{array}$ & function \\
\hline & & $\begin{array}{l}\text { - Support and cooperation for } \\
\text { strengthening the safety management } \\
\text { system of provincial and local } \\
\text { governments }\end{array}$ \\
& $\begin{array}{l}\text { Department of } \\
\text { Fomeland Security } \\
\text {-Establish emergency management } \\
\text { government } \\
\text { (DHS) }\end{array}$ & $\begin{array}{l}\text { Feoperation with relevant federal } \\
\text { Managementies, provincial and local }\end{array}$ \\
& Agency (FEMA) & $\begin{array}{l}\text { governments, voluntary organizations, } \\
\text { private companies, etc. } \\
\text {-Emergency management system based } \\
\text { on risk against disasters State }\end{array}$ \\
\hline & &
\end{tabular}




\begin{tabular}{|l|l|l|}
\hline \multirow{5}{*}{ State } & $\begin{array}{l}\text { Disaster } \\
\text { Management } \\
\text { Bureau } \\
\text { Disaster } \\
\text { Management Center }\end{array}$ & $\begin{array}{l}\text { - Coordinating and coordinating support } \\
\text { activities at the state level } \\
\text { - Management of mutual support } \\
\text { between local governments } \\
\text { - Large-scale disaster management that } \\
\text { local governments can not cope with }\end{array}$ \\
\hline \multirow{4}{*}{$\begin{array}{l}\text { Local } \\
\text { government }\end{array}$} & $\begin{array}{l}\text { Disaster } \\
\text { Management } \\
\text { Division } \\
\text { Regional Disaster } \\
\text { Management Center }\end{array}$ & $\begin{array}{l}\text { - Primary responsibility for public safety } \\
\text { - Creation and operation of emergency } \\
\text { operation plan } \\
\text {-Coordination of agencies and } \\
\text { mobilization of available resources in } \\
\text { case of disaster }\end{array}$ \\
\hline
\end{tabular}

Japan

According to the "Basic Law on Disaster Preparedness" in Japan, municipalities must take urgent measures to protect the lives, bodies and property of residents and ensure local safety when a disaster strikes. In addition, it has the most important duties, such as evacuation, boundary zone setting, fire fighting, and other measures, and the state and prefecture are supported by municipalities.

In addition, the "Basic Plan for Disaster Preparedness" establishes the "Central Disaster Prevention Conference" in the central government to protect the lives, bodies and property of the citizens, and the "Local Disaster Prevention Council" in the municipalities. Each disaster prevention conference plays a role of promoting comprehensive disaster countermeasures such as deliberating important matters concerning disaster prevention. "Central Disaster Prevention Conference" is called "Disaster Prevention Plan", "Local Disaster Prevention Conference" is "Local Disaster Prevention Plan" do.

If a disaster occurs and urgent measures are required, the central government can establish two countermeasures headquarters. In case of an emergency, the Emergency Response Headquarters should be designated as the Emergency Response Headquarters. In case of emergency, Can be installed. Prefectures and municipalities shall establish a "Disaster Countermeasures Headquarters" in the event of a disaster to respond to disasters.

\section{United Kingdom}

Disaster management in the UK is using bottom-up. The local government has all the authority and responsibilities for disaster response and restoration. It operates based on local responders. The role of the central government is to provide resources and cooperation to local governments.

In the UK, the local autonomy system is the foundation, and the central government provides a framework for disaster response, and the local government establishes and manages a crisis management plan at the regional crisis mitigation forum centered on the central framework of the central government. The Regional Crisis Mitigation Forum is a public-private cooperation organization in which local governments, military, media, companies, volunteer organizations participate. Each institution clearly exchanges information within the forum, clearly shares the role between the agencies in case of a disaster, Can not be done.

\section{Problems of Disaster Management System in Korea}

After the Sewol ferry incident, the government dismantled the
National Emergency Management Agency and the Marine Police Agency and transferred the functions of the Ministry of Maritime Affairs and Fisheries to the Ministry of Maritime Affairs and Fisheries. However, there is a lack of disaster management experts and a combination of different organizations, and the situation in case of a disaster. Problems such as lack of status system have arisen. Therefore, I would like to analyze the disaster management system of the present government and the problems of the organization on the basis of related laws such as "Basic Law on Disaster and Safety Management" and "Order of National Security Agency and its affiliated organization".

\section{Control tower element of disaster management organization}

The National Security Agency aims to establish a comprehensive disaster management system and to perform the function of a control tower to respond to disasters in the event of a disaster. However, in response to the National Security Agency's response to the accident on November 19, 2014, the Ministry of Foreign Affairs of the Ministry of Foreign Affairs of the Ministry of Foreign Affairs said, "The disaster is the main organ of the Ministry of Foreign Affairs. In this accident, the work done by the National Security Bureau was all that received the accident report and delivered it to the relevant authorities.

In addition, in response to the Mell crisis that occurred in May 2015, the National Security Service held a ministerial meeting of relevant ministries 12 days after the first confirmed patient occurred. It has been pointed out that the initial response failed because it could not be adjusted. In Article 3-2 of "Enforcement Ability of Disaster and Safety Management Act," disaster management officials are appointed for each type of disaster and accident, prepare. Response. And restoration work. This can be said to be the application of the integrated disaster management system that sets the responsible agency for each type of disaster and adjusts and controls the disaster related work in case of disaster. However, in the present situation, it is preceded to find out which ministry is the subject when the disaster occurs.

\section{Duplication of Disaster Management Organizations}

The disaster management organization system in Korea is a national disaster management organization and a disaster management organization when a disaster occurs or there is a concern. It is supposed to operate as a non-permanent organization centered on responsible organizations. These emergency epidemic disaster management organizations are redundantly installed in the central and provincial areas, and their composition is complicated and missions are not clearly assigned. In addition, the misunderstanding of the integrated disaster management method constitutes the disaster management organization form nationwide. This reduces the understanding of local conditions and characteristics and reduces their usefulness in individual disaster situations. In addition, top-down disaster management organizational structures and redundantly installed organizations will not be effective in an emergency disaster area due to complex reporting schemes and redundant instructions from each parent organization. 


\section{Inadequate Disaster Management Experts}

In the case of a central disaster management organization, the Countermeasures Headquarters is composed of civil servants who are not experienced in disaster response or lack expertise. And in the case of metropolitan and local governments, the disaster management department is felt as a one-off, avoiding capable employees. In this situation, local governments in the disaster area such as the Sewol ferrycase want the support of the central government without adequate response, and the central government establishes a response center for each relevant ministry. There is a case where the command system gets confused by operating.

\section{Formal Manual}

Based on the 33 types of crisis management manuals in Korea, including 13 types of security crisis, 11 types of disaster crisis, and 9 types of national core crisis, related departments created 278 crisis response manuals and 1300 related organizations And 2339 on-site action manuals have been established and operated.

There are many kinds of crisis management manuals in Korea, but they are not able to respond fully to disasters. Many complex manuals do not adequately reflect the disaster scene. In addition, manuals are different for each institution, information is not shared, and compatibility between manuals makes it difficult to respond to disasters. It is pointed out that the manual for the exhibition administration which is ignored in the field is a problem.

\section{Lack of capacity as a disaster management agency of local government}

Local governments are mainly engaged in the local disaster and safety headquarters. The head of the local disaster safety measures headquarters is head of the local government, and conducts disaster prevention situation investigation, restoration situation overall. And coordination. However, the disaster management system of local governments is not systematized unlike the central government.

Local governments are the closest administrative institutions to the public in the event of a disaster, and they should be responsible for the most important part of the initial disaster response, such as determining the situation at the forefront of the disaster site and conducting primary response to evacuate the residents. It does not have the ability to actually perform and adjust the disaster management function.

\section{Improving Disaster Management Policy in Korea}

\section{Legal aspects}

\section{(1) Construction of on-site command system}

There is a need to establish a standard field command system that can respond quickly, regardless of the type and size of the disaster. In the United States, there is an Incident Command System (ICS) system, which is applied not only to multiple disasters involving various organizations through a single standard field command system, but also to daily accidents that can be handled by institutions. In Korea, it is also necessary to introduce ICS into the disaster scene command system. In order to integrate the overall command system of the disaster site, the disaster response system in case of a disaster in the region or an accident is directed by the organization in accordance with the situation, and the local government plays a role to support the necessary resources and restoration activities. It is necessary to introduce it to the reality.

\section{(2) Unification of disaster law}

Disaster-related laws should be unified. There are about 70 laws related to disaster in Korea. Not only is there a lack of mutual connectivity in the contents of the law, but also there is a possibility that disorder and confusion arise because the response to disaster is focused on individual law. Therefore, it is necessary to integrate the maintenance of disaster-related laws so that the interrelationships between the laws are realized. To this end, it is necessary to examine the contents of the various stabilization measures prescribed in the individual laws, to include the common contents in the basic laws, and to take into account the relationship with other laws that each individual law should define.

That is, it is necessary to revise disaster related laws such as Disaster and Safety Management Basic Act, Natural Disaster Countermeasures Act, Civil Defense Basic Law, and so on to achieve the goal of disaster management administration to be integrated law instead of individual law based on current disaster and safety management basic law.

\section{Organizational aspects}

\section{(1) Establishment of disaster management department of local government}

The disaster management organization in Korea is operating as an emergency, so it is difficult to accumulate and learn about disasters. In addition, the disaster management department of the local government is recognized as an evasive department within the organization, and the circulation service system is operated, and after two to three years, the specialist is not available. The disaster management department is an organization that operates in a crisis situation. If the disaster preparedness is not thoroughly prepared, it is likely to develop into a major accident. Therefore, in order to establish a disaster response system for local governments, it is necessary to establish a disaster management department directly under the heads of local governments.

\section{(2) Strengthening the role of local government disaster management and cooperation with civilian organizations}

In order to prevent an effective disaster, It is necessary to establish disaster management measures that are appropriate to the social characteristics, and disaster management based on the site is needed to respond promptly and effectively to the disaster situation.

It is also important to work with private organizations as well as individual responses by local governments. Cooperation with civilian organizations in disaster management strengthens disaster management capabilities of local governments. Therefore, in the Disaster and Safety Management Basic Law, it is necessary to establish the basis for mutual cooperation of local governments by establishing the prestigious regulation on 
mutual cooperation between local autonomous bodies according to the disaster management stage.

\section{Personnel aspect}

(1) Disaster management education program management

(2) Training human resources for disaster management

In Korea, the recruitment of disaster management specialists is blocked by the recruitment of civil servants. In the mid- to long-term, students should strive to educate disaster prevention managers by establishing regular disaster-related departments and disaster management theory, safety management theory, disaster prevention engineering, urban planning and disaster prevention. In addition, practical disaster response drills should be carried out at each stage of disaster to nurture disaster response specialists to strengthen the training of experts.

\section{Financial aspects}

\section{(1) Strengthening Prevention}

Disaster management is divided into four phases: prevention, preparation, response, and recovery. However, disasters should be strengthened in prevention-oriented budgeting because prevention and preparation functions are important. Prevention, and preparation, it is necessary to invest a lot of budget for prevention and preparation so as to prevent a huge response and a recovery cost in advance in case of a major disaster.

(2) Disaster recovery budget schedule is organized as current expenses

Due to the nature of the disaster, most of the budget related to disaster recovery is organized as reserve funds due to uncertainties. However, this should be converted to current costs and made readily available.

\section{CONCLUSION}

The purpose of this paper is to suggest ways to improve the disaster management system in Korea. Based on this, we analyzed the problems and improvement plan of disaster management system in Korea.

In Korea's disaster management system, various government policies such as supplementation and maintenance of disaster management organization and system, establishment of special law, etc. were announced and improved every time a large-scale disaster occurred, but still, Many large and small disasters are occurring repeatedly.

As a result of analyzing the disaster management system in Korea, Legal aspect, organizational aspect, manpower aspect, and financial aspect. It is necessary to restructure the government in order to build a national safety net that enables the nation to live safely through improvement measures, and to establish a disaster management dedicated organization and response system in accordance with the actual situation of Korea. A safe Korea will be created when policies are established based on on-site response agencies and systems that oversee national security, and the safety awareness and safety culture of the public.

\section{ACKNOWLEDGMENT}

This work is financially supported by Minister of Public Safety and Security as $\ulcorner$ BK21 Plus Creative Technology of Crisis, Disaster and Risk Management $\lrcorner$.

\section{REFERENCES}

[1] Kim, Geon-wi, Improvement plan of local government disaster management system, Korea Institute of Local Administration (2008).

[2] Summit, Disaster Management Policy Issues and Plan, Homeland No. 417 (2016)

[3] Nachsen, disaster. A Study on the Improvement of Safety Related Laws, Final Report of the Korea Legislation Research Service (2014).

[4] Kim Eun Sung. Ahn, Hyeon - Keun, A Study on Effective Cooperation of Disaster Safety Management in Central Government and Local Government, KIPA Research Report (2009).

[5] Kim, Bong - Chul, Role of Local Governments in the Basic Act on Disaster and Safety Management and its Strengthening Plan, Korea Disaster Information Association (2014).

[6] Lim Hyun-il, Legal review for improvement of disaster management system in Korea, Master's thesis (2015), Graduate School of Public Administration and Law, Dankook University.

[7] Ko Chang-seok, A Study on the Improvement of Disaster Management System in Korea, Doctoral Thesis (2012), Kyung Hee University Graduate School of Public Administration.

[8] Baek Woo-chul, A Study on the Efficient System of Disaster Management, Master's Thesis, Kangwon National University (2009) 